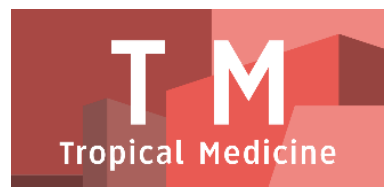

PAPER - OPEN ACCESS

\title{
Pengetahuan Perawat Tentang Perawatan Luka Dengan Metode Moist Wound Healing di RSUD H. Adam Malik Medan
}

Author : T. Widya Naralia

DOI $\quad: 10.32734 / \mathrm{tm} . v 111.38$

Paper Page : $75-79$

Volume 1 Issue 1 - 2018 TALENTA Conference Series: Tropical Medicine (TM)

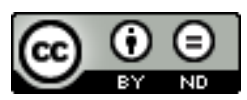

This work is licensed under a Creative Commons Attribution-NoDerivatives 4.0 International License.

Published under licence by TALENTA Publisher, Universitas Sumatera Utara
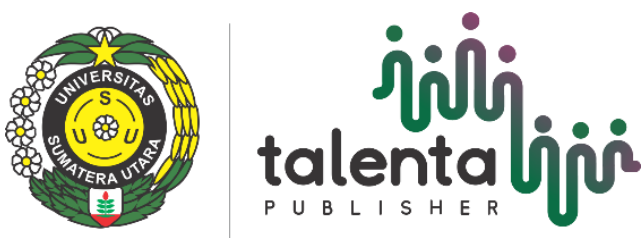


\title{
Pengetahuan Perawat Tentang Perawatan Luka Dengan Metode Moist Wound Healing di RSUD H. Adam Malik Medan
}

\author{
T. Widya Naralia ${ }^{\mathrm{a}, *}$, Yesi Ariani ${ }^{\mathrm{a}}$ \\ ${ }^{a}$ Fakultas Keperawatan, Universitas Sumatera Utara, Medan 20155
}

Email: widya.naralia@gmail.com

\begin{abstract}
Abstrak
Perawatan luka merupakan serangkaian kegiatan yang dilakukan untuk merawat luka dengan tujuan meningkatkan re-epitelisasi jaringan baru dan mengembalikan fungsi fisiologis kulit yang rusak. Moist wound healing merupakan metode perawatan luka terkini yang efektif menyembuhkan luka. Perawat dituntut untuk mempunyai pengetahuan dan keterampilan yang adekuat terkait dengan proses perawatan luka agar klien segera memperoleh kembali kesehatan dan kehidupan mandiri secara optimal. Penelitian ini menggunakan desain deskriptif yang bertujuan untuk mengidentifikasi pengetahuan perawat tentang perawatan luka dengan metode moist wound healing di RSUP H. Adam Malik Medan. Jumlah sampel penelitian ini adalah 60 orang perawat yang diambil melalui teknik total sampling sesuai kriteria inklusi yang ditetapkan yaitu perawat yang lama bekerja minimal 1 tahun di ruang bedah dan penyakit dalam serta pendidikan terakhir minimal D3 keperawatan. Hasil penelitian menunjukkan bahwa 50\% responden memiliki pengetahuan yang cukup, namun masih ada sebanyak $31,7 \%$ responden yang memiliki pengetahuan yang kurang tentang perawatan luka dengan metode moist wound healing. Disarankan bagi pihak RSUP. H. Adam Malik Medan agar dapat memfasilitasi pelatihan perawatan luka bagi perawat sehingga pengetahuan dan ketrampilan perawat menjadi lebih baik yang berdampak pada peningkatan kualitas asuhan keperawatan.
\end{abstract}

Kata kunci: Pengetahuan; Perawatan luka; Moist Wound Healing

\section{Pendahuluan}

Teknik perawatan dengan "moist wound healing" adalah metode untuk mempertahankan kelembaban luka dengan menggunakan bahan balutan penahan kelembaban sehingga menyembuhkan luka, pertumbuhan jaringan dapat terjadi secara alami. [12]. Perawatan luka saat ini masih cenderung menggunakan bahan-bahan perawatan yang konvensional dan tidak mendukung penyembuhan luka, seperti penggunaan povidone iodine maupun alkohol $70 \%$ yang masih digunakan untuk membersihkan luka. Cairan antiseptik ini akan menyebabkan luka mengering dan luka dianggap telah sembuh walau akhirnya malah menimbulkan bekas menghitam dan jaringan parut. Anggapan bahwa luka yang telah mengering adalah kondisi luka yang telah sembuh inilah yang harus diubah karena tidak sesuai dengan prinsip penyembuhan luka [3]. 
Perawat dituntut untuk mempunyai pengetahuan dan keterampilan yang adekuat terkait dengan proses perawatan luka yang dimulai dari pengkajian yang komprehensif, perencanaan intervensi yang tepat, implementasi tindakan, evaluasi hasil yang ditemukan selama perawatan serta dokumentasi hasil yang sistematis [13].

\section{Tujuan Penelitian}

Mengidentifikasi pengetahuan perawat tentang perawatan luka dengan metode moist wound healing di RSUP H. Adam Malik Medan.

\section{Metode}

Penelitian ini menggunakan desain penelitian deskriptif murni yang bertujuan mengidentifikasi pengetahuan perawat tentang perawatan luka dengan metode moist wound healing di RSUP H. Adam Malik Medan. Pengambilan jumlah sampel dilakukan dengan cara total sampling yaitu dengan mengacu pada kriteria inklusi dan eksklusi yang telah ditetapkan. Penelitian dilakukan di ruangan RA1, RB2A, RB2B, RB3 RSUP H. Adam Malik Medan. Diperoleh jumlah sampel perawat yang memenuhi syarat sebanyak 60 orang perawat.

\section{Hasil dan Pembahasan}

\subsection{Hasil Penelitian}

a. Karakteristik Responden

Hasil penelitian dari 60 responden yang terkumpul, diperoleh bahwa mayoritas responden yaitu berjenis kelamin perempuan sebanyak 55 orang $(91,7 \%)$, memiliki rentang usia dewasa awal 26-35 tahun 23 orang (38,3\%), pendidikan terakhir D3 Keperawatan 41 orang (68,3\%), lama bekerja dalam pelayanan keperawatan selama 1-10 tahun sebanyak 28 orang $(46,7 \%)$ dan responden dalam penelitian ini rata-rata belum pernah mengikuti pelatihan perawatan luka dengan metode moist wound healing yaitu sebanyak 51 orang (85\%).

b. Pengetahuan Perawat tentang Perawatan Luka dengan Metode Moist Wound Healing

Table 5.2. Distribusi Frekuensi dan Persentase Pengetahuan Perawat tentang Perawatan Luka dengan Metode Moist Wound Healing di RSUP H. Adam Malik Medan $(\mathrm{N}=60)$

\begin{tabular}{lcc}
\hline Pengetahuan Perawat & Frekuensi (n) & Persentase (\%) \\
\hline Baik & 11 & 18,3 \\
Cukup & 30 & 50 \\
Kurang & 19 & 31,7 \\
\hline
\end{tabular}

Hasil penelitian menunjukkan sebanyak 11 responden $(18,3 \%)$ memiliki pengetahuan dalam kategori baik, sebanyak 30 responden (50\%) memiliki pengetahuan dalam kategori cukup, dan 19 responden (31,7\%) memiliki pengetahuan dalam kategori kurang tentang perawatan luka dengan metode moist wound healing di RSUP H. Adam Malik Medan.

\subsection{Pembahasan}

Pengetahuan Perawat tentang Perawatan Luka dengan Metode Moist Wound Healing di RSUP H. Adam Malik Medan 
Pengetahuan merupakan apa yang diketahui atau hasil dari pekerjaan tahu seperti hasil dari kenal, mengerti dan pandai. Pengetahuan yang ada pada seseorang dipengaruhi oleh banyak faktor diantaranya pendidikan, pengalaman dan sumber informasi [10].

Hasil analisa pengetahuan perawat tentang perawatan luka dengan metode moist wound healing di RSUP H. Adam Malik Medan terhadap 60 orang perawat, diperoleh sebanyak 11 responden (18,3\%) memiliki pengetahuan dalam kategori baik, 30 responden (50\%) memiliki pengetahuan dalam kategori cukup, dan 19 responden $(31,7 \%)$ memiliki pengetahuan dalam kategori kurang. Hal ini dapat diasumsikan bahwa pengetahuan responden tentang perawatan luka dengan metode lembab tergolong masih rendah karena data menunjukkan mayoritas responden hanya memiliki pengetahuan dalam kategori cukup dan kurang. Hal tersebut diasumsikan karena hanya 9 orang $(15 \%)$ responden yang pernah mengikuti pelatihan tentang perawatan luka dengan metode moist wound healing atau perawatan luka modern. Sumber informasi bisa didapatkan melalui pelatihan-pelatihan yang dilakukan. Pelatihan merupakan salah satu sumber informasi yang menjadi perantara dalam menyampaikan informasi, merangsang pikiran dan kemampuan, dan menambah pengetahuan [10]. Hasil penelitian ini tidak sejalan dengan penelitian yang dilakukan Septiyanti (2014) bahwa lebih dari setengah total perawat $(59,3 \%)$ yang bekerja di ruangan medical surgical RS Eka Hospital Pekanbaru telah mampu memahami teknik perawatan luka dengan metode moist wound healing dengan baik. Tingginya tingkat pengetahuan perawat di Rumah Sakit Eka Hospital ini didukung oleh adanya sosialisasi metode perawatan luka dengan metode moist wound healing pada tahun 2011.

Tabel 5.3. Distribusi Frekuensi dan Persentase Hasil Identifikasi Pengetahuan Perawat tentang Perawatan Luka dengan Metode Moist Wound Healing di RSUP H. Adam Malik Medan $(\mathrm{N}=60)$

\begin{tabular}{|c|c|c|c|c|c|}
\hline \multirow[b]{2}{*}{ No } & \multirow[b]{2}{*}{ Pernyataan } & \multicolumn{2}{|c|}{ Benar } & \multicolumn{2}{|c|}{ Salah } \\
\hline & & F & $\%$ & $\mathrm{~F}$ & $\%$ \\
\hline 1. & Prinsip moist wound healing & 52 & 86,7 & 8 & 13,3 \\
\hline 2. & Manfaat perawatan luka lembab & 35 & 58,3 & 25 & 41,7 \\
\hline 3. & Tujuan perawatan luka lembab tertutup & 42 & 70 & 18 & 30 \\
\hline 4. & Tiga prinsip utama manajemen perawatan luka lembab & 16 & 26,7 & 44 & 73,3 \\
\hline 5. & Intervensi pertama untuk menentukan balutan luka & 36 & 60 & 24 & 40 \\
\hline 6. & Teknik pencucian luka & 48 & 80 & 12 & 20 \\
\hline 7. & Tipe cairan pencuci luka & 47 & 78,3 & 13 & 21,7 \\
\hline 8. & Pengkajian luka & 29 & 48,3 & 31 & 51,7 \\
\hline 9. & Defenisi autholisis debridement & 24 & 40 & 36 & 60 \\
\hline 10. & Pemilihan balutan tepat guna & 30 & 50 & 30 & 50 \\
\hline 11. & Luka dengan eksudat banyak menggunakan balutan & 42 & 70 & 18 & 30 \\
\hline 12. & Tujuan utama perawatan luka dengan warna dasar merah & 33 & 55 & 27 & 45 \\
\hline 13. & Tujuan utama perawatan luka dengan eksudatif & 47 & 78,3 & 13 & 21,7 \\
\hline 14. & Tujuan utama perawatan luka dengan warna dasar hitam & 30 & 50 & 30 & 50 \\
\hline 15. & Tujuan utama perawatan luka akut post-operasi & 48 & 80 & 12 & 20 \\
\hline 16. & Topikal terapi ideal untuk luka nekrotik hitam dan kering & 38 & 63,3 & 22 & 36,7 \\
\hline 17. & Topikal terapi ideal untuk luka dengan tepi luka tebal, mengeras & 25 & 41,7 & 35 & 58,3 \\
\hline 18. & Balutan ideal untuk luka dengan cairan eksudat & 24 & 40 & 36 & 60 \\
\hline
\end{tabular}

Hasil identifikasi pengetahuan perawat tentang perawatan luka dengan metode moist wound healing di RSUP H. Adam Malik Medan $(n=60)$ menunjukkan rata-rata responden sudah mengetahui tentang konsep dasar perawatan luka yang benar. Sebanyak 35 orang $(58,3 \%)$ responden sudah mengetahui bahwa manfaat perawatan luka lembab adalah mempercepat proses penyembuhan luka sesuai fisiologis tubuh. Sebanyak 42 orang (70\%) responden sudah mengetahui bahwa perawatan luka lembab tertutup bertujuan untuk meningkatkan re-epitelisasi jaringan baru. Metode perawatan luka lembab dengan balutan tertutup secara klinis memiliki keuntungan akan meningkatkan 
proliferasi dan migrasi dari sel-sel epitel disekitar lapisan air yang tipis, mengurangi resiko infeksi dan timbulnya jaringan parut [6].

Namun rata-rata perawat masih memiliki pengetahuan yang kurang tentang prinsip dan pemilihan balutan pada kondisi luka dengan karakteristik tertentu. Hal ini terlihat dari hasil penelitian menunjukkan hanya 16 orang $(26,7 \%)$ responden yang mengetahui prinsip utama manajemen perawatan luka. Data yang diperoleh menunjukkan kebanyakan responden menyatakan bahwa prinsip manajemen perawatan luka lembab sama dengan intervensi perawatan luka. Prinsip dari manajemen luka tergabung dalam pendekatan holistik atau secara keseluruhan. Penerapan prinsip dari manajemen luka harus mampu mengidentifikasi dan menentukan semua kebutuhan fisiologis pasien terkait dengan proses penyembuhan luka yaitu mengatasi penyebab luka, meningkatkan imunitas tubuh, dan menjaga kondisi fisiologis lingkungan luka. Kegagalan dalam menentukan prinsip manajemen luka dapat membahayakan seperti proses penyembuhan luka yang terhambat, penurunan daya tahan tubuh, komplikasi dan inflamasi yang berulang kemungkinan dapat terjadi [4].

Kurangnya pengetahuan perawat tentang pemilihan balutan yang tepat pada kondisi luka tertentu dapat dilihat dari data yang diperoleh yaitu hanya 25 orang $(41,7 \%)$ perawat yang mengetahui topikal terapi luka yang digunakan pada luka dengan tepi luka yang masih tebal, mengeras dan belum menyatu adalah hydrogel. Hanya 24 orang (40\%) perawat yang mengetahui jenis balutan ideal pada luka dengan banyak cairan eksudat adalah balutan alginate. Peneliti berasumsi bahwa ketidaktahuan perawat tersebut dikarenakan mayoritas perawat masih menggunakan jenis balutan yang sama untuk semua karakteristik luka yang berbeda. Biaya pembelian balutan occlusive modern lebih mahal dari balutan kasa konvensional, tetapi balutan modern dapat mengurangi frekuensi penggantian balutan dan meningkatkan kecepatan penyembuhan sehingga dapat menghemat biaya yang dibutuhkan [11]. Sesuai dengan penelitian yang dilakukan Ohura, Hiromi dan Yoshio (2004) tentang efektifitas pengeluaran biaya pada perawatan luka dengan balutan tradisional dan balutan modern. Hasilnya, total biaya yang digunakan selama 12 minggu untuk perawatan luka dengan derajat II dan III menunjukkan hasil pengeluaran biaya yang berbeda. Rata-rata biaya yang dikeluarkan pada perawatan luka dengan balutan modern yaitu sebesar 87,715 yen yang lebih rendah dibandingkan perawatan luka dengan balutan tradisional yang menggunakan kasa yaitu sebesar 131,283 yen.

\section{Kesimpulan}

Berdasarkan hasil analisa data dan pembahasan dapat diambil kesimpulan bahwa setengah dari total responden yaitu sebanyak 30 orang (50\%) responden memiliki pengetahuan yang cukup tentang perawatan luka dengan metode moist wound healing di RSUP H. Adam Malik Medan.

\section{Daftar Pustaka}

[1] Arikunto, S. (2006). Prosedur penelitian: Suatu pendekatan praktik. Edisi Revisi VI. Jakarta : Rineka Cipta

[2] Arisanty, I. P. (2012). Panduan praktis pemilihan balutan luka kronik. Jakarta : Mitra Wacana Medika

[3] Baroroh, B. D. (2011). Konsep luka. Diunduh pada 12 Oktober 2014 dari http://s1keperawatan.umm.ac.id/files/file/konsep\%20luka.pdf

[4] Bryant, R.A dan Nix, D. P. (2007). Acute \& chronic wounds : Current management concepts. Edisi 3. Philadelphia : Mosby Elseviercare clinician associate. Edisi 1. Bogor : CWCCAP

[5] Falanga et al. (2004). European Wound Management Association (EWMA). position document: Wound bed preparation in practice. London : MEP Ltd

[6] Maibach, Bashir \& McKibbon. (2002). Evidence-based dermatology. Canada : Bc Decker

[7] Maryunani, A. (2013). Perawatan luka modern praktis pada wanita dengan luka diabetes. Jakarta : Trans Info Media

[8] Morison, M. J. (2013). Manajemen luka. Jakarta : EGC

[9] Mwipatayi et al. (2005). Clinical experience - with activated polyacrylate dressing (Tenderwet 24). Journal of Royal Perth Hospital Australia, Vol : 13, No:2.

[10] Notoatmodjo, S. (2012). Promosi kesehatan dan perilaku kesehatan. Jakarta : Rineka Cipta

[11] Schultz et al. (2005). Wound healing and TIME; New concept and scientific applications : Wound repair and regeneration. 13 (4)

[12] Septiyanti, M. et al. (2014). Hubungan tingkat pengetahuan dengan sikap perawat tentang perawatan luka diabetes dengan menggunakan teknik moist wound healing. Program Studi Ilmu Keperawatan Universitas Riau.

[13] Sinaga, M. (2012). Gambaran penggunaan bahan pada perawatan luka di RSUD Dr. Djasamen Saragih Pematangsiantar. Medan : Fakultas Keperawatan USU 
[14] Sudjana. (2002). Metode Statistik, Edisi 6. Bandung :Tarsito

[15] White, Dr Barry. (2009). National best practice and evidence based guidelines for wound management. Irland: Health Service Executive [16] Wocare center, (2012). Buku panduan pelatihan perawatan luka : Certified wound WoundsWest Wound

[17] Prevalence Survey. (2011). State-wide overview report. Diunduh 23 Oktober 2014 dari https://www.health.wa.gov.au/WoundsWest/docs/WWWPS_11_state_report.pdf 